\title{
PERANAN MAJELIS PENGAWAS NOTARIS TERHADAP PELANGGARAN JABATAN DAN PERILAKU NOTARIS
}

\author{
Sjaifurrachman ${ }^{(1)}$ \\ Abshoril Fithry ${ }^{(2)}$ \\ ${ }^{(1,2)}$ Dosen Fakultas Hukum Universitas Wiraraja \\ sjaifurrachman@wiraraja.ac.id ${ }^{(1)}$ \\ abshorilfithry@wiraraja.ac.id ${ }^{(2)}$
}

\begin{abstract}
ABSTRAK
Notaris yang juga sebagai pejabat umum pembuat akta otentik perlu di awasi dan dilakukan pemeriksaan yang berkala agar nantinya perilaku notaris diharapkan sesuai dengan apa yang dicita-citakan baik oleh Peraturan Perundang-undangan, peraturan Menteri bahkan perilaku notaries yang sesuai dengan Kode Etik Notaris itu sendiri. Tujuan penelitian adalah Setiap dari penelitian pasti ada yang namanya tujuan penelitian, tujuan penelitian dalam penelitian ini adalah Untuk menderkripsikan dan menganalis syarat dan tata cara pengangkatan dan pemberhentian, susunan organisasi, tata cara pemeriksaan Majelis Pengawas Notaris serta pelaksanaan tugas dan wewenang majelis pengawas Notaris serta tata cara penjatuhan sanksi terhadap Notaris Metode pendekatan yang kami pakai adalah Pendekatan Perundang-undangan (Statute Approach) dilakukan dengan menelaah seluruh peraturan perundang-undangan yang sekiranya berkaitan dengan judul yang kami angkat diantaranya adalah Undang-undang Republik Indonesia Nomor 30 Tahun 2004 + Nomor 2 Tahun 2014 tentang Jabatan Notaris, Peraturan Menteri Hukum dan Hak Asasi Manusia Nomor : M.02.PR.08.10 Tahun 2004 tentang tata cara pengangkatan anggota, pemberhentian anggota, susunan organisasi, tata kerja dan tata cara pemeriksaan Majelis Pengawas Notaris, Keputusan Menteri Hukum dan Hak Asasi Manusia Republik Indonesia Nomor: M.39-PW.07.10 Tahun 2004 tentang Pedoman Pelaksanaan Tugas Majelis Pengawas Notaris, Peraturan Menteri Hukum dan Hak Asasi Manusia Republik Indonesia Nomor 40 Tahun 2015 tentang susunan organisasi, tata cara pengangkatan anggota, pemberhentian anggota, dan tata kerja Majelis Pengawas, Peraturan Menteri Hukum dan Hak Asasi Manusia Republik Indonesia Nomor 7 Tahun 20016 tentang Majelis Kehormatan Notaris, Peraturan Menteri Hukum dan Hak Asasi Manusia Republik Indonesia Nomor 61 tahun 2016 tentang Tata cara penjatuhan sanksi administratif terhadap Notaris, Surat Edaran Nomor 108/X/18/18 tahun 2018 tentang Pembinaan dan pengawasan Majelis Pengawas Notaris terhadap Perilaku dan Pelaksanaan Jabatan Notaris, Peraturan Menteri Hukum dan Hak Asasi Manusia Republik Indonesia Nomor 19 Tahun 2019 tentang Syarat dan tata cara pengangkatan, cuti, perpindahan, pemberhentian, dan perpanjangan masa jabatan Notaris, Perubahan Kode etik Notaris, Kongres Luar biasa Ikatan Notaris Indonesia, Banten, 29-30 Mei 2015, Standarisasi Operasional Prosedur (SOP) Majelis Pengawas Notaris
\end{abstract}

Kata Kunci : Peran, Pengawas, dan Pelanggaran 


\section{A. PENDAhuluan}

Banyak orang saat ini masih saja kebingungan dalam mencari pekerjaan, bahkan strata 1 pun dinilai masih kurang mumpuni untuk bekerja dalam satu bidang tertentu. Lulus kuliah malah kebingungan mau melanjutkan sekolah yang lebih tinggi/jenjang berikutnya atau berhenti saja langsung bekerja. Lulusan sarjana hukum saat ini yang ruang lingkup pekerjaannya sangat luas dan salah satunya adalah bekerja dengan Knowledge yang tinggi seperti Notaris.

Pekerjaan seperti Notaris inilah yang saat ini menjadi idaman anak-anak sarjana Lulusan s1 untuk melanjutkan ke jenjang yang lebih tinggi yaitu Magister Kenotariatan mengejar mimpi menjadi Notaris. Banyak yang berfikir bahwa menjadi seorang Notaris sangatlah menyenangkan, selain penghasilannya yang menjanjikan, seorang Notaris juga dapat membuka kantor sesuai dengan pilihannya sendiri yang diinginkannya setelah mendapatkan rekomendasi dari organisasi Notaris itu sendiri.

Saat ini profesi Notaris banyak pengawasnya, artinya profesi Notaris yang diidam-idamkan banyak orang tidak seperti yang dibayangkan. Mulai dari Dewan Kehormatan Notaris, Majelis Pengawas Notaris, Majelis Pengawas Daerah, Majelis Pengawas Wilayah, Majelis Pengawas pusat dan lain sebagainya membuat orang berfikir ribuan kali untuk menjadi Notaris. Banyaknya pelanggaran kode etik yang dilakukan Notaris serta perilaku Notaris saat ini menjadi focus pelanggaran yang sering dilakukan oleh kebanyakan Notaris.

Di dalam Undang-undang Republik Indonesia Nomor 30 Tahun 2004 + Nomor 2 Tahun 2014 tentang jabatan Notaris dalam pasal 1+ ayat 1 yang berbunyi bahwa Notaris adalah Pejabat umum yang berwenang untuk membuat akta autentik dan memiliki kewenangan lainnya sebagaimana dimaksud dalam Undang-undang ini atau berdasarkan Undang-undang lainnya. Oleh karena itu di dalam penjelasan umum Undang-undang tersebut Notaris sebagai pejabat umum yang menjalankan profesi dalam memberikan jasa hukum kepada masyarakat, perlu mendapatkan perlindungan dan jaminan demi tercapainya kepastian hukum.

Berdasarkan ketentuan bunyi pasal tersebut di atas sudah jelas bahwa Notaris berwenang untuk membuat akta otentik. Berdasarkan pada kewenangan itulah seorang Notaris harus bisa mempertanggung jawabkan akta yang telah dibuatnya apabila dikemudian hari terdapat pelanggaran maupun kelalaian pembuatan akta tersebut. Oleh karena itu jangan sampai seorang Notaris yang hanya karena ada kepentingan pribadi dan 


\section{IURNAL JENDELA HUKUM}

ISSN Cetak \& Online : 2355-5831/ 2355-9934

memihak pada salah satu kliennya membuat perilaku yang tidak professional sehingga nantinya dapat merugikan pihak yang lainnya. Apabila hal ini terjadi, maka kepercayaan masyarakat terhadap Notaris tersebut akan berkurang.

Menurut Komar Andasasmita dalam bukunya yang berjudul "Notaris dengan Sejarah, Peranan, Tugas Kewajiban, Rahasia Jabatannya mengatakan bahwa agar setiap Notaris mempunyai pengetahuan yang cukup luas dan mendalam serta keterampilan yang baik dalam merancang, menyusun, membuat berbagai akta otentik, susunan bahasa, tehnis yuridisnya rapi, baik dan benar, karena disamping keahlian tersebut diperlukan pula kejujuran, ketulusan dan memiliki sifat atau pandangan yang sesuai dengan keadaan yang sebenarnya. ${ }^{1}$

Selain tanggung jawab dan kewenangan membuat akta otentik tersebut Notaris juga terikat dengan yang namanya Kode Etik Notaris Ikatan Notaris Indonesia (I N I), mengatakan bahwa Notaris maupun orang lain (selama yang bersangkutan menjalankan jabatan Notaris) wajib :

1. Memiliki moral, akhlak serta kepribadian yang baik;

2. Menghormati dan menjunjung tinggi harkat dan martabat Jabatan Notaris;

${ }^{1}$ Komar Andasasmit, 1981, Notaris dengan sejarah, Peranan, Tugas dan Kewajiban, rahasia Jabatannya, Sumur, Bandung, h. 14
3. Menjaga dan membela kehormatan Perkumpulan;

4. Berperilaku jujur, mandiri, tidak berpihak, amanah, seksama, penuh rasa tanggung jawab, berdasarkan peraturan perundang-undangan dan isi sumpah Jabatan Notaris;

5. Meningkatkan ilmu pengetahuan dan keahlian profesi yang telah dimiliki tidak terbatas pada ilmu pengetahuan hukum dan kenotariatan;

6. Mengutamakan pengabdian kepada kepentingan masyarakat dan Negara;

7. Memberikan jasa pembuatan akta kewenangan lainnya untuk masyarakat yang tidak mampu tanpa memungut honorarium;

8. Menetapkan satu kantor di tempat kedudukan dan kantor tersebut merupakan satu-satunya kantor bagi Notaris yang bersangkutan dalam melaksanakan tugas jabatan seharihari;

9. Memasang 1 (satu) papan nama di depan/di lingkungan kantornya dengan pilihan ukuran yaitu $100 \mathrm{~cm}$ x $40 \mathrm{~cm}$, $150 \mathrm{~cm}$ x $60 \mathrm{~cm}$, atau $200 \mathrm{~cm} \times 80 \mathrm{~cm}$, yang memuat :

a. Nama lengkap dan gelar yang sah;

b. Tanggal dan nomor Surat Keputusan pengangkatan yang terakhir sebagai Notaris;

c. Tempat kedudukan

d. Alamat kantor dan nomor telepon/fax 
10. Dasar papan nama berwarna putih dengan huruf berwarna hitam dan tulisan di atas papan nama harus jelas dan mudah dibaca. Kecuali di lingkungan kantor tersebut tidak dimungkinkan untuk memasang papan nama yang dimaksud;

11. Hadir, mengikuti dan berpartisipasi aktif dalam kegiatan yang diselenggarakan oleh perkumpulan;

12. Menghormati; mematuhi, melaksanakan peraturan-peraturan dan keputusankeputusan perkumpulan;

13. Membayar uang Perkumpulan secara tertib;

14. Membayar uang duka untuk membantu ahli waris teman sejawat yang meninggal dunia;

15. Melaksanakan dan mematuhi semua ketentuan tentang honorarium yang ditetapkan Perkumpulan;

16. Menjalankan jabatan Notaris di kantornya, kecuali karena alasan-alasan tertentu;

Oleh sebab itu, untuk mengawasi perilaku dan pelaksanaan jabatan notaris maka menurut Pasal 67 ayat (5), Pasal 70 huruf a, g, pasal 71 huruf b,e Undangundang tentang Jabatan Notaris serta pasal 20, pasal 21, pasal 22, pasal 23, pasal 24, dan pasal 32 Permenkumham No.M.02.PR.08.10 tahun 2004 tentang tata cara pengangkatan anggota, pemberhentian anggota, susunan organisasi, tata kerja, dan tata cara pemeriksaan Majelis Pengawas Notaris, menteri selaku penyelenggara urusan pemerintahan di bidang hukum yang mengangkat dan memberhentikan Notaris, maka dalam melaksanakan pengawasan atas Notaris, Menteri membentuk Majelis Pengawas yang berjumlah 9 (Sembilan) orang, terdiri atas unsur: a. Pemerintah sebanyak 3 orang; b. Orgasisasi Notaris sebanyak 3 (tiga) orang; dan Ahli atau Akademisi sebanyak 3 (tiga) orang.

\section{B. PEMBAHASAN}

1. Syarat Dan Tata Cara Pengangkatan Dan Pemberhentian, Susunan Organisasi, Tata Cara Pemeriksaan Majelis Pengawas Notaris

Perlu diketahui bersama bahwa notaris mempunyai protokol notaris yang dibuat dari awal membuka kantor, menerima Surat Pengangkatan sebagai notaris hingga dilantik sampai aktif melaksanakan jabatannya sebagai notaris, notaris harus bisa membuat protokol notaris. Protokol adalah sekumpulan dokumen yang merupakan arsip negara yang harus disimpan dan dipelihara oleh notaris sesuai dengan peraturan perundang-undangan, dimana hal ini diatur di dalam undang-undang nomor 30 tahun 2004 jo undang-undang nomor 2 tahun 2014 tentang jabatan notarisserta undang-undang nomor 43 tahun 2009 


\section{IURNAL JENDELA HUKUM}

ISSN Cetak \& Online : 2355-5831/ 2355-9934

tentang kearsipan.

Dalam menjalankan tugas jabatan notaris salah satu kewajiban notaris dalam bidang administrasi tentunya adalah menyimpan dan memelihara segala dokumen termasuk diantaranya kumpulan akte dan berbagai dokumen lainnya yang biasa disebut protokol. Yang harus menjadi perhatian sebagai notaris dalam penyimpanan protokol terdapat di dalam pasal 62 undang-undang jabatan notaris menyebutkan bahwa protokol notaris itu terdiri dari minuta akta kemudian buku daftar akta atau reportorium kemudian ada buku daftar akte di bawah tangan atau legalisasi atauwarmeking, kemudian buku nama penghadap atau klapper, buku daftar protes, buku daftar wasiat, serta buku daftar lain yang harus disimpan oleh notaris berdasarkan ketentuan peraturan perundang-undangan, dan dari keseluruhan protokol tersebut setiap tahunnya diperiksa ataupun dibina oleh majelis pengawas daerah notaris apakah sudahrapi dan benar pembuatan reportorium yang sudah dikerjakan selama beberapa tahun selama notaris tersebut menjabat.

Selain itu yang paling penting dan wajib bagi notaris bahwa protokol merupakan aset yang nantinya akan dialihkan atau diserahkan apabila terjadi hal-hal yang akan dialami oleh notaris seperti contohnya apabila notaris tersebut meninggal dunia atau telah berakhir masa jabatannya atau notaris yang bersangkutan meminta sendiri untuk peralihan nya ataupun juga notaris yang bersangkutan sakit dalam hal ini secara jasmani maupun rohani sudah tidak mampu lagi melaksanakan tugas jabatannya sebagai notaris secara terusmenerus lebih dari 3 tahun serta diangkat sebagai pejabat negara, notaris pindah wilayah jabatan dan notaris diberhentikan sementara atau diberhentikan dengan tidak hormat. Hal-hal tersebut atau kejadian tersebut mewajibkan seorang notaris harus menyerahkan protokol yang dimilikinya yang dibuatnya kepada notaris yang ditunjuk untuk menerimanya. Oleh karena itu untuk menghindari dari hal-hal yang tidak mengenakan dikemudian hari maka protokol harus disimpan dengan baik oleh seorang notaris.

Untuk membahas lebih lanjut tentang protokol maka harus diketahui dulu apa arti atau pengertian dari seorang notaris karena adanya protokol pasti karena adanya seorang notaris. Motor sendiri pengertiannya ada di pasal 1 ayat 1 undang-undang nomor 30 tahun 2004 adalah pejabat umum yang berwenang membuat suatu akta otentik dan kewenangan lain sesuai dengan undangundang. Notaris sebagai pejabat yang umum itu merupakan pejabat yang sangat mulia artinya apa karena jabatan 


\section{IURNAL JENDELA HUKUM}

ISSN Cetak \& Online : 2355-5831/ 2355-9934

notarisitu diberikan kewenangan oleh negara menggunakan stempel jabatan dengan simbol negara kita bhinneka tunggal ika. Oleh karena itu jabatan notaris perlu dijaga harkat dan martabat jabatan notaris itu. Kita mengetahui bahwa notaris diangkat oleh pemerintah tujuannya untuk memberikan pelayanan kepada masyarakat sebagai pemangku kepentingan membuat akta otentik atau akta-akta yang dibuatnya harus sempurna, akta-akta yang dibuat oleh notaris dikenal dengan sebutan minuta. Minuta-minuta yang dibuat oleh notaris itu termasuk yang dikatakan sebagai protokol notaris.

Buku daftar akta atau reportorium harus dibuat oleh notaris, yang merupakan suatu dokumen yang memuat akta-akta yang dibuat oleh notaris. Notaris wajib memasukkan setiap akta yang dibuatsetiap harinya di dalam buku reportorium itu, yang bertujuan agar ada kepastian yang berhubungan dengan sumpah jabatan. Dari sumpah tersebut artinya notaris harus jujur dan tidak memihak.

Perlu diketahui bahwa minuta merupakan arsip negara. Oleh karena itu arsip negara itu harus dipelihara dengan sebaik-baiknya. Apabila terjadi hal-hal yang tidak diinginkan misalkan hilang atau rusak mata notaris harus melaporkan kepada majelis pengawas daerah. Apabila terjadi kebakaran maka notaris tersebut harus melaporkan kepada kepolisian sehingga nantinya mendapatkan berita acara dan setelah itu baru melaporkan kepada majelis pengawas daerah. Oleh karena itu para notaris harus menyimpan minuta akta dengan tertib, baik, aman dan benar.

Pemeriksaan rutin oleh majelis pengawas daerah notaris terhadap protokol Notaris yang merupakan Arsip Negara dapat dilakukan karena adanya laporan dari masyarakat kemudian pemeriksaan protokol Notaris yang dilakukan setiap tahun sedangkan yang ketiga berdasarkan fakta hukum terhadap dugaan pelanggaran pelaksanaan jabatan dan perilaku notaris.

Tata cara pemeriksaan yang dilakukan oleh Majelis Pengawas adalah sebagai berikut:

1. Syarat pengajuan laporan

2. Pemeriksaan administrasi pelaporan

3. Rapat gelar perkara

4. Pemeriksaan administrasi perkara

5. Pemanggilan

6. Pemeriksaan majelis pemeriksa

7. Materi acara pemeriksaan

8. Pemeriksaan protokol notaris

9. Pemeriksaan fakta hukum

Ruang lingkup pemeriksaan terhadap notaris dapat dilakukan karena adanya dugaan pelanggaran terhadap perilaku Notaris dan pelaksanaan jabatan notaris, yang di dalamnya terindikasi ada pelanggaran terhadap kode etik Notaris 


\section{IURNAL JENDELA HUKUM}

ISSN Cetak \& Online : 2355-5831/ 2355-9934

dan peraturan terhadap undang-undang jabatan notaris. Banyak orang mempersepsikan bahwa majelis pengawas daerah memeriksa juga pejabat pembuat akta tanah atau PPAT, perlu diketahui bahwa tugas dari majelis pengawas daerah tidak memeriksa pejabat pembuat akta tanah tapi lebih fokus pada pelanggaran yang terjadi terhadap kode etik Notaris dan peraturan jabatan notaris.

Pasal 18 permenkumham Nomor 15 tahun 2020 menyebutkan bahwa pemeriksaan oleh majelis pemeriksa daerah meliputi

a. Laporan pengaduan masyarakat

b. Pemeriksaan protokol notaris

c. Fakta hukum terhadap dugaan pelanggaran pelaksanaan jabatan dan perilaku notaris

Syarat pengajuan laporan melalui masyarakat dapat dilakukan oleh masyarakat yang merasa dirugikan akibat pelanggaran terhadap kode etik dan pelanggaran jabatan notaris, tentu saja hal ini dapat dilakukan dengan cara disertai bukti-bukti yang dapat dipertanggungjawabkan serta diajukan secara tertulis dalam bahasa Indonesia.

Selain itu pemeriksaan majelis pengawas daerah melalui majelis pemeriksa dapat dilakukan ketika mendapatkan laporan dari majelis pengawas daerah wilayah ataupun karena adanya fakta hukum lainnya. Biasanya Hal ini dapat diketahui dari hasil pemeriksaan protokol yang dilakukan oleh majelis pengawas daerah terhadap notaris yang dilakukan setiap tahun sekali. Biasanya di dalam aplikasi APN ada pertanyaan tentang fakta hukum Apakah Notaris yang bersangkutan mendapatkan sanksi atau tidak. Ketika majelis pengawas daerah notaris mengetahui adanya sanksi terhadap Notaris yang diperiksa, maka wajib hukumnya bagi majelis pengawas daerah notaris tersebut untuk menuliskan di dalam berita acara pemeriksaan protokol notaris tersebut, tentu saja hal tersebut dapat diproses lebih lanjut oleh majelis pengawas daerah yang berwenang.

Majelis pemeriksa biasanya berjumlah 3 orang yang terdiri dari 1 (satu) orang ketua dan 2 orang anggota yang ketiganya memenuhi unsur-unsur dari pemerintah, notaris serta akademisi, serta dibantu oleh satu orang sekretaris. Apabila salah satu dari majelis pemeriksa berhalangan hadir maka dapat digantikan oleh majelis pengawas dari unsur yang sama.

Setelah sekretaris majelis pengawas notaris memeriksa administrasi pelaporan yang meliputi identitas pelapor dan terlapor, surat laporan, serta buktibukti atau fakta hukum Maka selanjutnya dilakukan rapat gelar perkara. Rapat gelar perkara ini dilakukan oleh Ketua Majelis 


\section{IURNAL JENDELA HUKUM}

ISSN Cetak \& Online : 2355-5831/ 2355-9934

pengawas notaris. Rapat gelar perkara yang dilakukan setidaknya harus dihadiri oleh majelis pengawas notaris lainnya Hal ini diselenggarakan untuk mendengar duduk perkara dan penyampaian pendapat hukum oleh para anggota Majelis pengawas, penyampaian pendapat hukum tersebut dapat dijadikan sebagai masukan bagi majelis pemeriksa dalam memutus perkara yang berada dalam kewenangan pemeriksaannya. Setelah rapat gelar perkara dilakukan dan majelis pemeriksa telah terbentuk, maka sekretaris majelis pengawas dapat melakukan pemanggilan terhadap pelapor dan terlapor, dengan menggunakan surat tercatat atau surat elektronik atau melalui faksimili paling lambat 5 hari sebelum sidang pemeriksaan.

Apabila dalam jadwal pemanggilan terlapor tidak hadir setelah dipanggil secara patut dan sah maka dapat dilakukan pemanggilan kedua, apabila terlapor tetap tidak hadir setelah dipanggil secara patut dan sah untuk yang kedua kalinya maka pemeriksaan dilakukan dan tetap dilakukan pengambilan keputusan yang diucapkan tanpa kehadiran dari terlapor. Apabila pelapor yang tidak hadir setelah dipanggil secara sah dan patut dapat juga dilakukan pemanggilan yang kedua, apabila pemanggilan kedua dilakukan secara sah dan patut tetapi pelapor tetap tidak hadir maka majelis pemeriksa menyatakan laporan gugur dan tidak dapat diajukan kembali, hal ini kemudian dimasukkan di dalam berita acara yang selanjutnya disampaikan kepada ketua Majelis pengawas notaris.

Majelis pemeriksa dapat memulai pemeriksaan paling lama 7 hari sejak majelis pemeriksa ditetapkan artinya majelis pemeriksa harus segera melaksanakan pemeriksaan terhadap pelapor maupun terlapor. Selain itu juga majelis pemeriksa daerah harus menyelesaikan dan menyampaikan hasil pemeriksaannya paling lama 30 hari terhitung sejak laporan dicatat di buku register perkara.

Pemeriksaan tersebut nantinya akan dihadiri oleh pelapor maupun terlapor yang meliputi pembacaan laporan dan keterangan pelapor serta pembelaan diri dari terlapor. Dalam pemeriksaan ini juga pelapor maupun terlapor diberi kesempatan untuk menyampaikan tanggapan hal-hal apa saja yang nantinya dapat disampaikan di depan majelis pemeriksa. Dalam hal menyampaikan tanggapan pelapor dan terlapor juga dapat mengajukan bukti untuk mendukung dalil yang diajukan. Hasil pemeriksaan tersebut nantinya harus dituangkan dalam berita acara pemeriksaan dan rekomendasi hasil pemeriksaan kepada majelis pengawas notaris.

Tata cara pengangkatan dan pemberhentian anggota Majelis pengawas 


\section{IURNAL JENDELA HUKUM}

ISSN Cetak \& Online : 2355-5831/ 2355-9934

notaris terdapat di dalam pasal 2 peraturan menteri hukum dan Ham nomor M.02.PR.08.10 Tahun 2004 Tentang pemberhentian anggota susunan organisasi dan tata kerja, dan tata cara pemeriksaan majelis pengawas notaris.

Di dalam pasal 2 terdapat syaratsyarat untuk diangkat menjadi anggota pengawas notaris diantaranya adalah:

a. Warga negara Indonesia

b. Bertakwa kepada Tuhan Yang Maha Esa

c. Pendidikan paling rendah sarjana hukum

d. Tidak pernah dihukum karena melakukan tindak pidana yang diancam dengan pidana penjara 5 tahun atau lebih

e. Tidak dalam keadaan pailit

f. Sehat jasmani dan rohani

g. Berpengalaman dalam bidangnya paling rendah 3 tahun

Untuk pengusulan anggota Majelis pengawas dilakukan dengan ketentuan sebagai berikut:

\section{Majelis Pengawas Daerah}

1. Pengusulan anggota Majelis pengawas daerah dilakukan dengan ketentuan sebagai berikut:

a. Unsur pemerintah oleh Kepala Divisi pelayanan hukum kantor wilayah b. Unsur organisasi notaris oleh pengurus daerah Ikatan Notaris Indonesia

c. Unsur ahli/ akademisi oleh pemimpin fakultas hukum atau perguruan tinggi setempat

2. Dalam hal Kabupaten/ kota tertentu Tidak ada fakultas hukum atau Sekolah Tinggi Ilmu Hukum, menunjukkan unsur ahli/ akademisi ditentukan oleh Kepala Kantor Wilayah atau pejabat yang ditunjuknya

3. Masing-masing unsur sebagaimana dimaksud pada ayat 1 mengusulkan 3 orang calon anggota Majelis pengawas daerah

4. Dalam hal syarat dan pengusulan untuk dapat diangkat sebagai anggota Majelis pengawas daerah telah terpenuhi sebagaimana dimaksud dalam pasal 2 dan pada ayat 3, Kepala Kantor Wilayah mengangkat anggota Majelis pengawas daerah dengan surat keputusan

Majelis Pengawas Wilayah

1. Pengusulan anggota Majelis pengawas wilayah dilakukan dengan ketentuan sebagai berikut

a. Unsur pemerintah oleh kepala kantor wilayah

b. Unsur organisasi notaris oleh pengurus wilayah Ikatan Notaris Indonesia 


\section{c. Unsur ahli/akademisi oleh pemimpin fakultas hukum atau perguruan tinggi setempat}

2. Dalam hal pada provinsi tertentu Tidak ada fakultas hukum atau perguruan tinggi, penunjukan unsur ahli/akademisi ditentukan oleh menteri atau pejabat yang ditunjuk

3. Masing-masing unsur sebagaimana dimaksud pada ayat 1 mengusulkan 3 orang calon anggota Majelis pengawas wilayah

4. Dalam hal syarat dan pengusulan untuk dapat diangkat sebagai anggota Majelis pengawas wilayah telah terpenuhi sebagaimana dimaksud dalam pasal 2 dan pada ayat 3, Direktur Jenderal administrasi hukum umum mengangkat anggota Majelis pengawas wilayah dengan surat keputusan

Majelis Pengawas Pusat

1. Pengusulan anggota Majelis pengawas pusat dilakukan dengan ketentuan sebagai berikut

a. Unsur pemerintah Oleh Direktur Jenderal administrasi hukum umum, unsur organisasi notaris oleh pengurus pusat Ikatan Notaris Indonesia

b. Unsur ahli/akademisi oleh Dekan Fakultas Hukum Universitas yang menyelenggarakan program magister kenotariatan.
2. Masing-masing unsur sebagaimana dimaksud pada ayat 1 mengusulkan 3 orang calon anggota Majelis pengawas Pusat

3. Dalam hal syarat dan pengusulan untuk dapat diangkat sebagai anggota Majelis pengawas pusat telah terpenuhi sebagaimana dimaksud dalam pasal 2 dan pada ayat 2, Menteri mengangkat anggota Majelis pengawas pusat dengan surat keputusan

Sedangkan untuk pemberhentian majelis pengawas notaris terdapat di dalam pasal 9 yaitu:

1. Anggota Majelis pengawas notaris diberhentikan Dengan hormat dari jabatannya karena:
a. Meninggal dunia
b. Telah berakhir masa jabatannya
c. Permintaan sendiri
d. Pindah Wilayah kerja

2. Anggota Majelis pengawas notaris diberhentikan dengan tidak hormat dari jabatannya karena:

a. Dipidana berdasarkan putusan pengadilan yang telah mempunyai kekuatan hukum tetap yang diancam dengan pidana penjara 5 tahun atau lebih

b. Usul dari majelis pengawas pusat kepada Menteri

c. Dalam hal anggota Majelis pengawas notaris diduga 
melakukan tindak pidana, yang bersangkutan diberhentikan sementara dari jabatannya untuk memudahkan pemeriksaan proses peradilan.

3. Dalam hal anggota Majelis pengawas Notaris dan unsur organisasi Ikatan Notaris Indonesia diberhentikan sementara dari jabatannya selaku notaris berdasarkan ketentuan dalam pasal 9 undang-undang tentang jabatan notaris, demi hukum berhenti sebagai anggota Majelis pengawas notaris

4. Dalam hal anggota Majelis pengawas notaris dari unsur organisasi Ikatan Notaris Indonesia diberhentikan dengan tidak hormat dari jabatannya selaku notaris berdasarkan ketentuan dalam pasal 12 undang-undang tentang jabatan notaris, demi hukum berhenti sebagai anggota Majelis pengawas notaris.

Susunan organisasi dan tata kerja majelis pengawas notaris terdiri atas majelis pengawas daerah majelis pengawas wilayah dan majelis pengawas Pusat. Majelis pengawas notaris beranggotakan 9 orang terdiri atas 1 orang ketua merangkap Anggota, satu orang wakil ketua merangkap anggota, dan 7 orang anggota. Ketua dan wakil ketua dipilih dari dan oleh anggota yang dilakukan secara musyawarah atau pemungutan suara.

Di dalam pasal 12 :
1. majelis pengawas notaris dibantu oleh satu orang sekretaris atau lebih yang ditunjuk dalam rapat majelis pengawas notaris

2. sekretaris majelis pengawas notaris sebagaimana dimaksud pada ayat satu harus memenuhi persyaratan sebagai berikut

A. Berasal dari unsur pemerintah

B. Mempunyai golongan ruang paling rendah $3 / b$ untuk majelis pengawas daerah

C. Mempunyai golongan ruang paling rendah 3/d untuk majelis pengawas wilayah dan majelis pengawas Pusat

D. Tempat kedudukan Kantor Sekretariat majelis pengawas notaris untuk tingkat majelis pengawas Daerah berada pada kantor unit pelaksana teknis Departemen hukum dan hak asasi manusia atau tempat lain di Ibukota kabupaten/kota yang ditunjuk oleh Kepala Kantor Wilayah, majelis pengawas wilayah berada di kantor wilayah, majelis pengawas pusat berada di kantor Direktorat Jenderal administrasi hukum umum, Departemen hukum dan hak asasi manusia Republik Indonesia

Untuk tata kerja majelis pengawas notaris diatur di dalam pasal 13 yang berbunyi:

1. Kewenangan majelis pengawas daerah yang bersifat administratif 


\section{IURNAL JENDELA HUKUM}

ISSN Cetak \& Online : 2355-5831/ 2355-9934

dilaksanakan oleh ketua, wakil ketua, atau salah satu anggota, yang diberi wewenang berdasarkan keputusan rapat majelis pengawas daerah

2. Kewenangan sebagaimana dimaksud pada ayat 1 meliputi:

A. Memberikan izin cuti untuk jangka waktu sampai dengan 6 bulan

B. Menetapkan notaris pengganti

C. Menentukan tempat penyimpanan protokol Notaris yang pada saat serah terima protokol notaris telah berusia 25 tahun atau lebih

D. Menerima laporan dari masyarakat mengenai adanya dugaan pelanggaran kode etik notaris atau pelanggaran ketentuan dalam undang-undang dibukukan, dan daftar surat lain yang diwajibkan oleh undang-undang

E. Menerima penyampaian secara tertulis salinan dari daftar akta, daftar surat dibawah tangan yang disahkan, dan daftar surat dibawah tangan yang dibukukan yang telah disahkannya, yang dibuat pada bulan sebelumnya paling lambat 15 hari kalender pada bulan berikutnya, yang memuat sekurang-kurangnya nomor tanggal dan judul akta.

Kewenangan majelis pengawas daerah yang bersifat administratif yang memerlukan keputusan rapat adalah: a. Menunjuk Notaris yang akan bertindak sebagai pemegang protokol Notaris yang diangkat sebagai pejabat negara

b. Menunjuk Notaris yang akan bertindak sebagai pemegang protokol Notaris yang meninggal dunia, memberikan persetujuan atas permintaan penyidik penuntut umum atau Hakim untuk proses peradilan

c. Menyerahkan fotokopi minuta akta dan atau surat-surat yang dilekatkan pada minuta akta atau protokol notaris dalam penyimpanan protokol

d. Memanggil notaris untuk hadir dalam pemeriksaan yang berkaitan dengan akta yang dibuatnya atau protokol Notaris yang berada dalam penyimpanan notaris

Pasal 15 menyebutkan :

1. Majelis pengawas daerah sebelum melakukan pemeriksaan berkala atau pemeriksaan setiap tahun yang dianggap perlu, dan yang terlebih dahulu memberitahukan secara tertulis kepada Notaris yang bersangkutan paling lambat 7 hari kerja sebelum pemeriksaan dilakukan

2. Surat pemberitahuan sebagaimana dimaksud pada ayat 1 mencantumkan jam hari tanggal dan nama anggota Majelis pengawas daerah yang akan melakukan pemeriksaan 
3. Pada waktu yang ditentukan untuk dilakukan pemeriksaan Notaris yang bersangkutan harus berada di kantornya dan menyiapkan sama protokol notaris

Pasal 16 menyebutkan :

1. Pemeriksaan secara berkala dilakukan oleh tim pemeriksa yang terdiri atas 3 orang anggota dari masing-masing unsur yang dibentuk oleh majelis pengawas daerah yang dibantu oleh satu orang sekretaris

2. Tim pemeriksa sebagaimana dimaksud pada ayat 1 wajib menolak untuk memeriksa Notaris yang mempunyai hubungan perkawinan Apa hubungan darah dalam garis lurus ke atas atau ke bawah tanpa pembatasan derajat, dan garis lurus ke samping sampai dengan derajat ketiga dengan notaris

3. Dalam hal tim pemeriksa mempunyai hubungan sebagaimana dimaksud pada ayat 2, Ketua Majelis pengawas daerah menunjuk penggantinya

Pasal 17 menyebutkan :

1. Hasil pemeriksaan tim pemeriksa sebagaimana dimaksud dalam pasal 15 dituangkan dalam berita acara pemeriksaan yang ditandatangani oleh ketua tim pemeriksa dan Notaris yang diperiksa

2. Berita acara pemeriksaan sebagaimana dimaksud pada ayat 1 disampaikan kepada majelis pengawas wilayah setempat dengan tembusan kepada Notaris yang bersangkutan, pengurus daerah Ikatan Notaris Indonesia, dan majelis pengawas Pusat.

Pasal 18 Menyebutkan :

1. Kewenangan majelis pengawas wilayah yang bersifat administratif dilaksanakan oleh ketua, wakil ketua, atau salah satu anggota yang Diberi wewenang berdasarkan keputusan rapat majelis pengawas wilayah

2. Kewenangan sebagaimana dimaksud pada ayat 1 adalah memberikan izin cuti untuk jangka waktu 6 bulan sampai dengan 1 tahun.

Pasal 19 menyebutkan :

1. Kewenangan majelis pengawas pusat yang bersifat administratif dilaksanakan oleh ketua wakil ketua, atau salah satu anggota yang Diberi wewenang berdasarkan keputusan rapat majelis pengawas Pusat.

2. Kewenangan sebagaimana dimaksud pada ayat 1 adalah memberikan izin cuti untuk jangka waktu lebih dari 1 tahun

\section{Pelaksanaan Tugas Dan Wewenang} Majelis Pengawas Notaris Serta Tata Cara Penjatuhan Sanksi

\section{Terhadap Notaris}

Didalam permenkumham nomor 15 tahun 2020 tentang tata cara pemeriksaan majelis pengawas notaristepatnya di dalam pasal 1 


\section{IURNAL JENDELA HUKUM}

ISSN Cetak \& Online : 2355-5831/ 2355-9934

menyebutkan bahwa majelis pengawas notaris adalah suatu badan yang mempunyai kewenangan dan kewajiban melaksanakan pembinaan dan pengawasan terhadap notaris. Pembinaan dan pengawasan terhadap tentara tersebut biasanya dilakukan setiap tahun sekali yaitu pada waktu pemeriksaan protokol notaris.

Majelis pengawas berwenang melakukan pembinaan dan pengawasan terhadap notaris serta melakukan pemeriksaan terhadap dugaan pelanggaran perilaku dan pelaksanaan jabatan notaris. Tetapi di dalam masyarakat berkembang istilah bahwa seorang notaris biasanya juga adalah seorang PPAT, hal ini sangat berbeda sekali karena majelis pengawas hanya berwenang melakukan pemeriksaan terhadap dugaan pelanggaran yang terjadi pada perilaku dan jabatan notaris bukan PP PPATnya.

Majelis pengawas Notaris yang berwenang melakukan pembinaan dan pengawasan terhadap notaris serta pemeriksaan terhadap dugaan pelanggaran perilaku dan pelaksanaan jabatan notaris terbagi menjadi beberapa wilayah diantaranya:

1. Majelis pengawas daerah

2. Majelis pengawas wilayah

3. Majelis pengawas Pusat

Dan dari ketiga majelis pengawas tersebut dibantu oleh satu orang sekretaris. Sekretaris inilah nantinya yang akan membantu majelis pengawas notaris untukmembantu hal-hal yang dibutuhkan oleh majelis pengawas.Majelis pengawas daerah dalam kewenangannya dapat menerima laporan dari masyarakat karena adanya dugaan pelanggaran kode etik Notaris dan peraturan pada jabatan notaris. Ketua Majelis pengawas daerah paling lambat 5 hari kerja setelah Laporan diterima membentuk majelis pemeriksa daerah dan masing-masing unsur yang terdiri atas 1 orang ketua dan 2 orang anggota Majelis pemeriksa dibantu oleh satu orang sekretaris.

Kewenangan majelis pemeriksa terhadap pemeriksaan awal pada pelaporan

a. Syarat pelapor adalah pihak yang merasa dirugikan yaitu:

- Pihak dalam akta yaitu orang yang berkepentingan langsung pada akta atau ahli waris.

- Orang yang memperoleh hak atas ahli waris

b. Syarat laporan

- Syarat pelaporan harus disampaikan secara tertulis

- Selain itu syarat laporan harus disertai dengan bukti awal yang dapat dipertanggungjawabkan Selain itu majelis pemeriksa juga mempunyai kewenangan untuk melakukan pemeriksaan berdasarkan dari surat tugas yang diberikan oleh Ketua Majelis pengawas daerah. Tentu saja 


\section{JURNAL JENDELA HUKUM}

ISSN Cetak \& Online : 2355-5831/ 2355-9934

pemeriksaan ini berbeda dengan pemeriksaan yang dilakukan di dalam pengadilan dalam sidang pemeriksaan yang dilakukan terhadap pelanggaran dugaan pelanggaran kode etik dan pelanggaran jabatan notaris dilakukan dalam sidang tertutup untuk umum dan hasilnya bersifat rahasia dan biasanya pemeriksaan ini dilakukan paling lambat 7 hari setelah Laporan diterima.

Pada sidang pertama majelis pemeriksa melakukan pemeriksaan terhadap:

- Pelapor dengan meminta konfirmasi untuk memperjelas laporan pengaduan adanya dugaan pelanggaran jabatan notaris dan kode etik notaris serta mendengar keterangan pelapur yang disertai dengan bukti awal yang dapat dipertanggungjawabkan

- Pemanggilan berikutnya biasanya yang dipanggil adalah terlapor, dengan meminta klarifikasi atau penjelasannya mengenai indikasi dugaan pelanggaran, untuk itu sekaligus terlapor diberi kesempatan yang cukup untuk menyampaikan tanggapan.

Jika pemeriksaan dipandang cukup, maka majelis pemeriksa menyatakan selesai dan selanjutnya sidang diskors untuk memberi kesempatan kepada majelis pemeriksa bermusyawarah untuk membuat kesimpulan dan rekomendasi. Jadi majelis pemeriksa tidak bisa membuat keputusan ataupun memberikan vonis terhadap notaris tersebut, yang bisa dilakukan oleh majelis pemeriksa hanya memberikan kesimpulan dan rekomendasi kepada majelis pengawas daerah.

Dari hasil pemeriksaan tersebut baik pemeriksaan pelapor maupun terlapor kesemuanya dituangkan di dalam berita acara pemeriksaan yang ditandatangani oleh ketua dan sekretaris. Pelapor maupun terlapor tidak dimintai tanda tangan.

Dalam hal majelis pemeriksaan notaris menemukan dugaan adanya unsur pidana yang dilakukan oleh terlapor, maka majelis pemeriksaan notaris wajib memberitahukan kepada majelis pengawas daerah dan majelis pengawas daerah tersebut wajib melaporkan kepada instansi yang berwenang.

\section{Majelis Pengawas Wilayah}

Majelis pengawas wilayah dibentuk berdasarkan undang-undang jabatan notaris yaitu pada pasal 72, pasal 73 ayat 1 huruf a, b, c, d, e, f, pasal 74, pasal 75 permenkumham No.M.02.PR.08.10 Tahun 2004 pasal 20 , pasal 21, pasal 22, pasal 25, pasal 26, pasal 27, pasal 31, pasal 32, pasal 33, dan pasal 34. Selain itu majelis pengawas wilayah juga dibentuk berdasarkan pada permenkumham Nomor 61 tahun 2016 yaitu pada pasal 3, pasal 4, pasal 5 dan pasal 6 .

Kewenangan dari majelis 


\section{IURNAL JENDELA HUKUM}

ISSN Cetak \& Online : 2355-5831/ 2355-9934

pengawas wilayah ini biasanya menerima hasil pemeriksaan dari majelis pengawas daerah mengenai dugaan adanya pelanggaran kode etik Notaris dan atau au peraturan jabatan notaris dan Ketua Majelis pengawas wilayah paling lambat 5 hari kerja membentuk majelis pemeriksa wilayah dari masing-masing unsur yang terdiri atas 1 orang ketua dan 2 orang anggota Majelis pengawas wilayah dan dibantu oleh satu orang sekretaris.

Kewenangan majelis pemeriksa wilayah dapat dijabarkan sebagai berikut:

1. Pemeriksaan awal terhadap pelaporan

a. Syarat pelapor ( pihak yang merasa dirugikan)

b. Syarat laporan ( adanya dugaan pelanggaran disertai bukti awal)

2. Pemanggilan

a. Ketua Majelis pemeriksa wilayah melakukan pemanggilan terhadap pelapor dan terlapor paling lambat 5 hari kerja sebelum sidang.

b. Jika terlapor setelah dipanggil secara sah dan patut tetapi tidak hadir maka dilakukan pemanggilan kedua, Namun apabila juga tetap tidak hadir maka pemeriksaan dilakukan tanpa kehadiran terlapor.

c. Jika pelapor setelah dipanggil secara sah dan patut tidak hadir, maka dilakukan pemanggilan yang kedua, dan apabila pelapor tetap tidak hadir maka majelis pemeriksa wilayah menyatakan laporan gugur dan tidak dapat diajukan lagi.

3. Pemeriksaan

a. Dilakukan dalam sidang tertutup untuk umum.

b. Dimulai paling lambat 7 hari kalender setelah Laporan diterima.

c. Pemeriksaan paling lambat 30 hari kalender, keputusan harus diucapkan dalam sidang terbuka untuk umum.

d. Pada sidang pertama majelis pemeriksa wilayah melakukan pemeriksaan terhadap:

- Pelapor tentang adanya dugaan pelanggaran an peraturan jabatan notaris dan kode etik notaris serta mendengar keterangan pelapur yang disertai bukti awal yang dapat dipertanggungjawabkan.

- Terlapor diberi kesempatan untuk menyampaikan tanggapan.

e. Pelapor dan terlapor dapat mengajukan pembelaan diri baik secara lisan maupun secara tertulis dengan mengajukan bukti-bukti dan saksi-saksi untuk mendukung dalil yang diajukan.

- Majelis pemeriksa wilayah melakukan serangkaian pemeriksaan lebih lanjut dengan cara:

- Meminta keterangan kepada pelapor, terlapor, saksi saksi dari pihak terkait lainnya serta 
meminta dokumen-dokumen terkait lainnya sebagai barang bukti.

- Meneliti dan menelaah atau menganalisa alat-alat bukti tersebut dari laporan hasil pemeriksaan majelis pengawas daerah guna memberi keyakinan tentang terbukti atau tidaknya suatu dugaan pelanggaran kode etik Notaris dan peraturan jabatan notaris.

f. Jika pemeriksaan dipandang cukup, maka majelis pemeriksa wilayah menyatakan selesai dan selanjutnya sidang diskors untuk memberi kesempatan kepada majelis pemeriksa wilayah untuk bermusyawarah guna membuat kesimpulan dan keputusan atau rekomendasi.

g. Hasil pemeriksaan dituangkan juga di dalam berita acara pemeriksaan yang didalamnya ditandatangani oleh ketua dan sekretaris. Sekretaris majelis pemeriksa wilayah menyelesaikan minutasi berkas sidang pemeriksaan dan membuat salinannya.

h. Jika majelis pemeriksa wilayah menemukan dugaan adanya unsur pidana yang dilakukan oleh terlapor, maka majelis pemeriksa wilayah wajib memberitahukan kepada majelis pengawas wilayah dan dugaan unsur pidana yang Diberitahukan kepada majelis pengawas wilayah wajib dilaporkan kepada instansi yang berwenang.

4. Mengambil keputusan

a. Putusan harus memuat alasan dan pertimbangan yang cukup, yang dijadikan dasar untuk menjatuhkan putusan.

b. Apabila di antara anggota Majelis pemeriksa wilayah tidak tercapai mufakat maka keputusan diambil dengan suara terbanyak.

c. Putusan harus diucapkan dalam sidang terbuka untuk umum titik dalam hal terdapat perbedaan pendapat diantara sesama anggota Majelis pengawas wilayah maka perbedaan pendapat tersebut dimuat dalam putusan.

d. Putusan ditandatangani oleh ketua, anggota, dan sekretaris majelis pemeriksa wilayah.

e. Jika laporan tidak dapat dibuktikan, maka majelis pemeriksa wilayah mengucapkan putusan yang menyatakan laporan ditolak dan terlapor direhabilitasi nama baiknya.

f. Jika laporan dapat dibuktikan, maka terlapor dijatuhi sanksi sesuai dengan tingkat pelanggaran yang dilakukan.

g. Jika majelis pemeriksa wilayah memutuskan terlapor terbukti melakukan pelanggaran kode etik Notaris dan peraturan jabatan notaris, 
maka terhadap terlapor dikenai sanksi berupa:

- Peringatan tertulis

- Pemberhentian sementara

- Pemberhentian dengan hormat

- Pemberhentian dengan tidak hormat Penjatuhan sanksi tersebut dapat dilakukan secara berjenjang atau tanpa berjenjang.

h. Untuk memberikan sanksi:

- Peringatan tertulis ( bersifat final) karena:

Melanggar ketentuan pasal 7 ayat 1, pasal 16 ayat 1 huruf a sampai dengan huruf L pasal 17 ayat 1, Pasal 19 ayat 1, Pasal 32 ayat 1, 2, 3, pasal 37 ayat 1, Pasal 54 ayat 1, Pasal 58 dan pasal 59 undang-undang jabatan notaris.

- Mengusulkan kepada majelis pengawas pusat untuk pemberian sanksi berupa pemberhentian sementara karena:

- Dalam proses pailit

- Berada dibawah Pengampuan

- Melakukan perbuatan tercela

- Melakukan pelanggaran terhadap kewajiban sekaligus larangan

- Sedang menjalani masa penahanan Pemberhentian dengan tidak hormat karena:

- Dinyatakan pailit berdasarkan putusan pengadilan

- Berada dibawah Pengampuan secara terus-menerus lebih dari 3 tahun
- Melakukan perbuatan yang merendahkan kehormatan jabatan notaris

- Melakukan pelanggaran berat terhadap kewajiban dan larangan jabatan secara terus menerus

Dalam hal pemberian sanksi secara berjenjang dapat berupa:

- Peringatan tertulis dengan menetapkan kewajiban yang harus dipenuhi notaris dalam waktu 14 hari atau dalam waktu tertentu ternyata: belum memenuhi kewajiban atau menyelesaikan masalah atau melakukan atau Mengulangi kesalahan dapat dikenakan sanksi peringatan tertulis kedua dan seterusnya. Apabila ternyata tidak juga dipenuhi dalam waktu yang ditetapkan, maka majelis pengawas wilayah dapat mengajukan usulan sanksi pemberhentian sementara kepada majelis pengawas Pusat.

i. Salinan putusan majelis pemeriksa wilayah disampaikan kepada Menteri, pelapor terlapor, majelis pengawas daerah, dan pengurus pusat Ikatan Notaris Indonesia, paling lambat 30 hari kalender terhitung sejak putusan diucapkan.

Majelis pengawas Pusat

Majelis pengawas pusat dibentuk atas dasar undang-undang jabatan notaris yaitu pada pasal 76 , pasal 77 pasal 78 


\section{IURNAL JENDELA HUKUM}

ISSN Cetak \& Online : 2355-5831/ 2355-9934

pasal 79 pasal 80., serta permenkumham No.M.02/Th 2004 yang terdapat di dalam pasal 35, sedangkan an permenkumham Nomor 61 tahun 2016 dasar pembentukan dari majelis pengawas pusat berada pada pasal 7 pasal 8 pasal 9 dan pasal 10 .

Kewenangan yang diberikan kepada majelis pengawas pusat sebagai berikut:

- Menerima hasil pemeriksaan majelis pemeriksa wilayah:

Usulan sanksi pemberhentian sementara atau pemberhentian dengan tidak hormat.

- Membentuk majelis pemeriksa pusat untuk:

Melakukan pemeriksaan awal:

- Hasil pemeriksaan majelis pengawas wilayah berikut keputusannya

- Memori banding

- Kontra memori banding

- Melakukan pemanggilan

Pemanggilan yang dilakukan oleh majelis pemeriksa Pusat semuanya harus dihadiri oleh pembanding dan terbanding

- Melakukan pemeriksaan

Meminta keterangan pembanding dan terbanding, serta pembuktian dengan meminta keterangan saksi dan bukti dokumen

Pemeriksaan protokol notaris

a. Pemeriksaan protokol notaris:

- $\quad$ secara berkala 1 kali dalam satu tahun

- Setiap waktu yang dianggap perlu b. Pemeriksaan secara berkala dilakukan oleh tim pemeriksa terdiri 3 orang dari masing-masing unsur dibantu oleh satu orang sekretaris.

c. Majelis pengawas daerah terlebih dahulu memberitahukan secara tertulis kepada notaris paling lambat 7 hari kerja sebelum pemeriksaan dilakukan tim pemeriksa dengan mencantumkan jam hari tanggal pemeriksaan.

d. Pemeriksaan protokol notaris meliputi:

1) Kedudukan notaris, surat pengangkatan sebagai notaris, berita acara sumpah jabatan notaris, surat penetapan cuti Notaris, dan sertifikat cuti notaris.

2) Protokol notarisyang terdiri dari:

- Bundel minuta akta

- Bundel warkah akta

- Bundel legalisasi

- Bundel waarmerking

- Buku daftar akta atau reportorium

- Buku legalisasi

- Buku waarmerking

- Buku daftar protes

- Buku daftar wasiat

Tim pemeriksa memeriksa pengamanan penyimpanan protokol kemudian mencatat tanggal pemeriksaan dan jumlah aktor atau surat sejak tanggal pemeriksaan terakhir serta menandatangani buku daftar protokol. 
3) Tim pemeriksa memeriksa:

- Minuta dengan melakukan uji petik

- Laporan bulanan

- Pemegang protokol notaris purna tugas

- Jumlah pegawai

- Sarana dan prasarana kantor antara lain bisa komputer, meja lemari dan mesin ketik.

4) Tim pemeriksa mengevaluasi pemeriksaan dan memberi penilaian:

- Tingkat kepatuhan notaris terhadap kode etik Notaris dan peraturan jabatan notaris

- Hasil evaluasi digunakan sebagai bahan untuk melakukan pembinaan dan pengawasan

- Menindaklanjuti hasil evaluasi dengan memberikan penghargaan kepada Notaris yang mematuhi ketentuan kode etik Notaris dan peraturan jabatan notaris sanksi kepada Notaris yang tidak mematuhinya.

5) Hasil pemeriksaan:

- Bersifat rahasia ( isi akta dan hasil pemeriksaan )

- Hasil pemeriksaan tersebut dituangkan dalam berita acara pemeriksaan yang ditandatangani oleh ketua tim pemeriksa dan sekretaris.

- Setelah berita acara tersebut ditandatangani oleh ketua tim pemeriksa dan sekretaris maka berita acara pemeriksaan an-nissa paikan kepada majelis pengawas wilayah dengan tembusan kepada Notaris yang bersangkutan, organisasi Notaris, dan majelis pengawas Pusat.

\section{KESIMPULAN}

\section{Kesimpulan}

Tata cara pengangkatan dan pemberhentian, susunan organisasi, tata cara pemeriksaan Majelis Pengawas Notaris dibagi menjadi beberapa tingkatan, yaitu Majelis Pengawas Daerah, yang apabila semua persyaratan sudah terpenuhi maka Kepala Wilayah mengangkat anggota Majelis Pengawas dengan surat keputusan, sedangkan untuk Majelis Pengawas Wilayah diangkat oleh Direktur Jendral Administrasi Umum, dan untuk Majelis Pengawas Pusat diangkat oleh Menteri. Kesemuanya majelis pengawas terdiri dari 9 orang yang masing-masing terdiri dari tiga unsur yaitu Notaris, akademisi serta pemerintahan yang dibantu oleh satu orang sekretaris

Pelaksanaan tugas dan wewenang majelis pengawas Notaris serta tata cara penjatuhan sanksi terhadap Notaris biasanya dapat dilakukan oleh majelis pengawas notaris melalui majelis pemeriksa notaris. Majelis pemeriksa Notaris ini dapat memeriksa apabila yang pertama terdapat laporan masyarakat, pemeriksaan tahunan, serta adanya fakta hukum. Pemberian sanksi akan diberikan 
kepada notaris apabila notaris yang bersangkutan terbukti melanggar kode etik notaris dan pelanggaran jabatan notaris.

\section{Saran}

Diharapkan nantinya pengangkatan majelis pengawas notaris dapat diperpanjang masa baktiya yang semula hanya tiga tahun, diubah menjadi empat tahun mengingat pentingnya suatu pemeriksaan terhadap protokol Notaris.

Diharapkan kedepannya kewenangan dari majelis pemeriksa notaris tidak hanya memberikan rekomendasi saja kepada majelis pengawas notaris, tetapi juga dapat memberikan putusan terhadap notaris yang terbukti melanggar kode etik dan pelanggaran jabatan notaris di wilayahnya masing-masing.

\section{DAFTAR BACAAN}

\section{Buku}

Andi Pangerang Moenta,. Syafaat Anugrah Pradana Pokok-pokok Hukum Pemerintahan Daerah, Rajawali Press, Depok. 2017,

Ashshofa, Burhan, 2007, Metodologi Penelitian Hukum, Jakarta: Rineka Cipta

Budi Agus Riswandi dan Sabhi Mahmashani, 2009, Dinamika Hak Kekayaan Intelektual dalam Masyarakat Kreatif, Total Media, Yogyakarta

G.H.S. Lumban Tobing, 1999, Peraturan jabatan Notaris, Erlangga: Jakarta

Habib Adjie, 2013, Menjalin pemikiranpendapat tentang Kenotariatan (kumpulan Tulisan), PT. Citra Aditya Bakti, Bandung

Komar Andasasmita, 1981, Notaris dengan sejarah, peranan, tugas kewajiban, rahasia jabatannya, Sumur, Bandung
Soejono Soekanto dan Sri Manidji, 2003, Penelitian Hukum Normatif suatu Tinjauan Singkat, Jakarta: Raja Grafindo Persada

Sjaifurrachman dan Habib adjie, 2011, Aspek Pertanggung jawaban Notaris Dalam Pembuatan Akta, Bandung

Zainudin Ali, 2009, Metode Penelitian Hukum, Sinar Grafika

\section{Undang-Undang:}

Undang-undang Republik Indonesia Nomor 30 Tahun 2004 + Nomor 2 Tahun 2014 tentang Jabatan Notaris,

Peraturan Menteri Hukum dan Hak Asasi Manusia Nomor : M.02.PR.08.10 Tahun 2004 tentang tata cara pengangkatan anggota, pemberhentian anggota, susunan organisasi, tata kerja dan tata cara pemeriksaan Majelis Pengawas Notaris,

Keputusan Menteri Hukum dan Hak Asasi Manusia Republik Indonesia Nomor: M.39PW.07.10 Tahun 2004 tentang Pedoman Pelaksanaan Tugas Majelis Pengawas Notaris, 